\title{
Elaborating an Innovative Model of Educational Process Management, Designed for Adaptation to the Changes in External Institutional Environment
}

Vorontsova L.V.a

Ismagilova G.N. ${ }^{b}$

Kramin T.V.c

Timiryasova A.V. ${ }^{d}$

\author{
acd Institute of Economics, Management and Law, Kazan, Russian Federation, 420111 \\ ${ }^{b}$ Kazan Federal University, Institute of Management, Economics and Finance, Kazan, 420008, Russia
}

\section{Doi:10.5901/mjss.2015.v6n1s3p179}

\section{Abstract}

The work views the requirements to the modern educational process and its features. An additional set of competences is proposed and discussed, which is necessary for ensuring students' competitiveness in the modern labor market. The contours of the innovative model of educational process management are drawn, which is designed for adaptation to the changes in the external institutional environment. The authors prove the transactional character of costs of introducing the model and offer a classification of these costs.

Keywords: innovative model of educational process management, educational process, institutional environment, transactional costs, cost approach, institutional approach.

The modern stage of society development is characterized by the forming on a new economy - an economy based on knowledge. Information and knowledge become investment assets, providing competitive advantage, and, consequently, one of the main sources of wealth (Becker, 2009; Mintrom, 2009; Schultz, 1971). Under these conditions, the role of educational system dramatically increases, as it is designed or creating, distributing and confirming knowledge. At the same time the informational revolution requires its radical change to adapt to new conditions, including the modern institutional environment (Elmore, 1997; Schneckenberg, 2009; Vaira, 2004). The proposed work builds the contours of the innovative model of educational process management, designed for adaptation to the changes in the external institutional environment.

The model should, first of all, take into account the modern realia. At present, it is obvious that the traditional transfer of knowledge from the professor to the student is not only inefficient, but also useless. The recently adopted in Russia Federal state educational standard gives a new direction based on competence approach. Competence development of the students is a necessary but insufficient condition for turning knowledge into innovative valuable products. It is necessary to create conditions for easier and stimulating transfer of information and knowledge into innovative intelletual products. Thus, special attention should be paid to the development of the institutional environment of the educational process.

G. Konstantinov and S. Filonovich highlight the following new trends of the informational society development ${ }^{1}$ (Константинов \& Филонович, 2005):

1) The paradox of informational saturation, which was brightly expressed in the number of "internet-plagiarism" incidents at western universities (literature survey on topic: Park, 2003; Walker, 1998); the essence of the phenomenon is that the availability of information on the Internet demotivates the students for creating new knowledge. Moreover, the students passively receive the available information, taking the adopted knowledge for their own, while the new knowledge is formed on the personal interpretation of information, comparing it with personal experience and further critical analysis;

2) The paradox of uncertainty, connected with the volume of available information. It leads to the growth of alternatives and, consequently, creates uncertainty when making decisions. The search for more information

\footnotetext{
1 See also (Shenton, 2007).
} 
to reduce uncertainty only increases it (van Asselt \& Vos, 2006).

3) The paradox of education, which consists in the fact that the value of the acquired knowledge (in a knowledgebased society) decreases with time. While the period of acquiring knowledge is 4-6 years, it approaches the period of the knowledge half-life (the period during which $50 \%$ of information becomes obsolete; in hightechnology sphere this period is about two years; in other spheres it is longer, but it rarely exceeds 7 - 8 years). Thus, the simple transfer of knowledge is senseless and is not the main objective of education (Dahlman, 2009, p. 274; Frasher, 1969, p. 6).

4) The paradox of studying. In the traditional education, the most important component was remembering. However, the rapid deterioration of knowledge requires the skills of timely clearing information, or "the skill of forgetting". This fact was mentioned in the work by P.M. De Holan, N. Phillips, \& T.B. Lawrence, (De Holan, Phillips, \& Lawrence, 2004), devoted to the research of the so called "studying organizations".

During the formation of knowledge-based economy, the knowledge becomes a particular product and forms its own sector of economy - the sector of producing and improving knowledge (Britz, Ponelis, \& Lor, 2013; Dunkin, 2002; Slabbert, 1996). The modern education must consider this fact. To be competitive, the graduates of educational establishments should not only be able to use the acquired knowledge. They should also be able to independently create new knowledge, in compliance with personal needs and the needs of the society.

The above trends and realia require the development of a number of qualitatively new competences of students:

1) Competences of intellectual leadership (leadership skills in intellectual activity): going beyond the frameworks of existing approaches, purposefulness, patience, inspiration, responsibility, etc.;

2) Skills of information processing and analysis, modelling, abstract and imaginative thinking;

3) Skills of interdisciplinary research;

4) Intuitive thinking based on the skills of knowledge and experience interpretation;

5) Intellectual cooperation and knowledge exchange.

Appropriate new institutions should be formed to develop the above competences.

In general, the economic system competitiveness in the epoch of knowledge-based economy depends on the degree of efficiency of knowledge creation and distribution. The higher the intellectual capital profitability, the higher the investment potential and competitiveness of the economic system (Н. Кочеткова \& Крамин, 2011; Н. В. Кочеткова, 2011).

Transactional costs play a special role in forming the profitability of intellectual capital (Brewer \& McEwan, 2010; Murphy \& Louis, 1999), as they have informational character. The above transformations significantly change the institutional environment: there appears a lot more information, information deterioration becomes quicker, etc., consequently, the existing transactional costs increase, and the new ones appear. Ignoring this trend leads to the significant growth of transactional costs, and intellectual capital profitability reduction. That is why the innovative model of educational process management should be based of transactional costs management, which, in turn, should be based on cost approach.

In general, transactional costs management can be carried out not only by managing particular kinds of transactional costs (Rowan, Meyer, \& Rowan, 2006). The institutional environment of the educational process produces a significant and complex influence on its composition and structure (Rowan et al., 2006). Its development can systematically reduce transactional costs. Thus, introduction of new institutions into the educational process can also increase the efficiency of the intellectual capital forming and using. Consequently, knowing the bases of institutional theory, ability to use them and create new knowledge in this sphere is the key characteristics (and competence) of the modern competitive specialist.

Thus, the innovative model of educational process management is based on the chain of value creation, which begins with investing into informational resources and ends at creating innovative products (see Fig.1). 


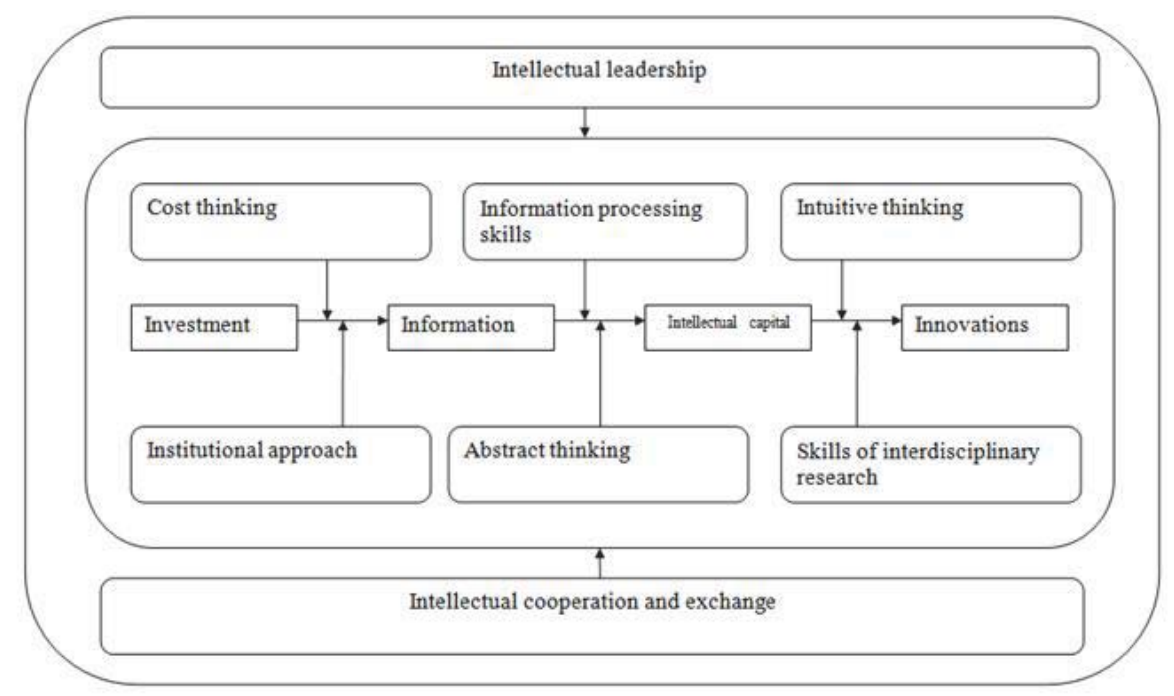

Fig.1. Innovative model of educational process in the knowledge-based economy.

The model shown in Fig.1 in the most general terms describes the process of investments transformation into innovative products. In the educational sphere one should extinguish several groups of investment objects: administrativemanagerial personnel, lecturers, consumers of educational services. Besides direct acquisition of informational resources it is necessary to invest into the development of competences and skills shown in Fig.1, which are used for efficient transformation of information into innovative valuable products (including the stage of innovations commercialization). Besides, it is necessary to ensure the efficient use of the allocated resources. The administrative-managerial personnel should be interested in acquiring the cost and institutional approaches. Intellectual leadership skills, skills of cooperation and exchange should spread along the personnel of an educational establishment. The lecturers should be motivated not only to develop their own skills of information processing and abstract thinking, by to form these qualities in students. The lecturers should also be interested in developing intuitive thinking in students, as well as teaching to use interdisciplinary research tools. Intuitive thinking is also an inseparable characteristics of a successful leader which helps them to make right strategic decisions in due time under uncertainty and insufficiency of information. The modern scientific research cannot be carried out without interdisciplinary approach. A lot of inventions have been made recently at the verge of several sciences and sectors of knowledge. The high potential of interdisciplinary research has not been fully realized yet.

All above skills must be formed in students.

The above innovative model can face serious difficulties due to the low students' interest in forming these competences. The skills development can also contradict to the interests of the personnel of an educational establishment. Finally, opportunistic manifestations among the lecturers can hinder the process of skills transfer.

The most general solution of this problem is forming the stimulating institutional environment - a system of intraorganizational and public institutions (rules), providing the necessity of mastering these skills. The costs of creating such system should be attributed to the first group of transactional costs.

The second way of solving the above problem is to work in the sphere of agent's relations. In this case, transactional costs will be represented by agent's costs.

\section{References}

Becker, G. S. (2009). Human capital: A theoretical and empirical analysis, with special reference to education: University of Chicago Press.

Brewer, D. J., \& McEwan, P. J. (2010). Economics of education: Elsevier Science.

Britz, J., Ponelis, S., \& Lor, P. J. (2013). Distinguishing right from wrong: proposed ethical principles for the development of national information policies. Innovation: journal of appropriate librarianship and information work in Southern Africa: Ethical dimension of social media in the information society(47), 9-27.

Dahlman, C. J. (2009). Education and growth of servicesThe Service Revolution in South Asia (pp. 233): Poverty Reduction and Economic Management Unit, South Asia Region.

Tsertseil, J.S. The way of clusters uprising and development in the region (By the example of the petrochemical cluster in the republic of 
Tatarstan). Mediterranean Journal of Social Sciences, Volume 5, Issue 18 SPEC. ISSUE, 2014, Pages 125-128

Safina, D., Podgornaya, A. (2014). Mobbing as an organizational phenomenon impeding implementation of changes. Mediterranean Journal of Social Sciences, 5 (18 SPEC. ISSUE), pp. 187-192

De Holan, P. M., Phillips, N., \& Lawrence, T. B. (2004). Managing organizational forgetting. MIT Sloan Management Review, 45(2), 4551.

Dunkin, R. (2002). Higher Education, Students, Society: Multi-lateral Relationships. Responding to student expectations.

Elmore, R. F. (1997). The paradox of innovation in education. Innovation in American government: Challenges, opportunities, and dilemmas, 246-273.

Frasher, R. D. (1969). An Appraisal of the Status and Future of the Continuing Education (Non-Credit) for Engineers in the United States.

Ablaev I.M., Khovanskaya E.S. Essence and Economical Substance of Innovative Cluster in Territorially Localized Business System// Mediterranean Journal of Social Sciences.- Vol.5, No12, (2014)-pp.159 - 162.

Nagimova, A.M., Safiullina, F.R. (2014). Combination of university training with employment among Kazan' students. Sotsiologicheskie Issledovaniya, (4), pp. 121-124.

Mintrom, M. (2009). Universities in the knowledge economy: A comparative analysis of nested institutions. Journal of Comparative Policy Analysis, 11(3), 327-353.

Murphy, J., \& Louis, K. S. (1999). Handbook of research on educational administration : a project of the American Educational Research Association (J. Murphy \& K. S. Louis Eds. 2 ed.). San Francisco: Jossey-Bass Publishers.

Park, C. (2003). In other (people's) words: Plagiarism by university students--literature and lessons. Assessment \& Evaluation in Higher Education, 28(5), 471-488.

Rowan, B., Meyer, H., \& Rowan, B. (2006). The new institutionalism and the study of educational organizations: Changing ideas for changing times. The new institutionalism in education, 15-32.

Schneckenberg, D. (2009). Understanding the real barriers to technology-enhanced innovation in higher education. Educational Research, 51(4), 411-424.

Schultz, T. W. (1971). Investment in Human Capital. The Role of Education and of Research.

Shenton, A. K. (2007). The paradoxical world of young people's information behavior. School Libraries Worldwide, 13(2), 1-17.

Slabbert, A. (1996). Capitalism at the crossroads. International Journal of Social Economics, 23(9), 41-50.

Vaira, M. (2004). Globalization and higher education organizational change: A framework for analysis. Higher Education, 48(4), 483-510. van Asselt, M. B. A., \& Vos, E. (2006). The precautionary principle and the uncertainty paradox. Journal of risk research, 9(4), 313-336.

Walker, J. (1998). Student plagiarism in universities: what are we doing about it? Higher Education Research \& Development, 17(1), 89106. 